\title{
Streamlining Molecular Pathobiology of Malignant Melanoma
}

\author{
Gérald E Piérard ${ }^{1 *}$, Claudine Piérard-Franchimont ${ }^{2}$, Philippe Humbert $^{3}$, Philippe Delvenne $^{2}$ \\ ${ }^{1}$ Laboratory of Skin Bioengineering and Imaging, Department of Clinical Sciences, University of Liège, 4000 Liège, Belgium \\ ${ }^{2}$ Department of Dermatopathology, University Hospital of Liège, Liège, Belgium \\ ${ }^{3}$ Department of Dermatology, University Hospital Saint-Jacques, University of Franche-Comté, Besançon, France
}

Received: May 30, 2016; Accepted: June 16, 2016; Published: June 30, 2016

*Corresponding author: Gérald E Piérard, Department of Dermatopathology, University Hospital of Liège, BE-4000 Liège, Belgium, E-mail : gerald.pierard@ulg.ac.be

\begin{abstract}
Currently, regular histopathology and immunohistochemistry are commonly taken for granted in the diagnosis of Cutaneous Malignant Melanoma (CMM). In addition, attempts at molecular diagnosis in dermatopathology have benefited from advances in pathobiology genomics and proteomics. They provide utmost information for optimal patient care. Sensitive techniques detect specific DNA and RNA sequences, and molecular methods were refined in the field of polypeptides. This review aims at covering on an overall glance about molecular genetics available as diagnostic supports in CMM. Laboratory methods have disclosed and highlighted some pathogenic pathways of atypical melanocytic neoplasms with particular emphasis on the activation of the Mitogen-Activated Protein Kinase (MAPK) signalling pathway (including BRAF and KIT) during the initiation step of the neoplasms. Many familial CMM contain mutations of the tumor suppressor gene p16 or CDKN2A. In addition, mutations in p53 are found in distinct CMM types. Many CMM are likely related to a variety of common low penetrance genes. Molecular dermatopathology represents a promising tool for both research and diagnosis. Knowledge of tumor mutation status is becoming increasingly important. The expected benefit of molecular dermatopathology tends to ultimately improve the targeted patient management. Such method evolution points to a need for improving the routine training requirements for dermatopathologists involved in cancer diagnostic responsibilities.
\end{abstract}

Keywords: Melanoma; Morphobiology; In Situ Hybridization; Polymerase Chain Reaction; Mutation

\section{Introduction}

Cutaneous Malignant Melanoma (CMM) is commonly a deadly and most chemoresistant form of skin cancer. It surges following some specific genetic and environmental impacts leading to oncogenic transformation of normal regular melanocytes. The problem is real at the present time because CMM incidence is steadily rising worldwide [1]. Identifying CMM with confidence is commonly assessed after careful microscopic examination. However, routine histopathology occasionally remains a challenging procedure in this field [2]. It is hindered by a set of clinical and histopathological limitations in both repeatedly defining objective criteria, and drawing-up are undisputable diagnostic consensus. The problem is more complex for occult or clinically undetectable micrometastases. Some of them correspond to single CMM cells disseminated at distance from larger tumors. They represent hypothetical dormant metastases [3] or conversely active proliferating cells responsible for neoplastic deposits corresponding to for future clinically recognizable metastases [4]. The disease-free interval occasionally extend over 10-40 years.

Translational research is essential and newsworthy to innovations in CMM care. Over recent decades, CMM immunopathology shifted the diagnosis process from descriptive morphology to more accurate information focusing on neoplastic cell phenotype and proliferation rate [4 -6]. Currently, immunopathology helps distinguishing among a set of atypical melanocytic neoplasms, and supports attempts to precise CMM staging [4-11]. The aspect of the peritumoral stroma is moreover informative $[12,13]$. However, predictive markers of therapeutic response are not yet established by these methods so far. Of note, in depth research pushes CMM diagnosis beyond regular microscopy to the domains of molecular biology and molecular morphology. They are focused on mutations in DNA, RNA and proteins. Such specific and sensitive procedures applied to CMM help refining the diagnosis, classification, outcome prediction, as well as selection and monitoring of therapy [14-26].

Recent advances in skin biology led to the identification of a series of gene products that are frequently involved in malignant transformation of melanocytes. In particular, they involve recognition of $\mathrm{CMM}$ stem/progenitor cells, starting from CMM tumoral initiation and going on progression to a locally advanced condition and to the metastatic disease [25]. Knowledge of CMM mutation status is becoming increasingly important for treatment, because mutation-specific inhibitors are developed for clinical use. In CMM, alterations in mitogen genes activate the protein kinase (MAPK) pathway. Deregulated gene products encompass the oncogenic BRAF V600E [23, 27, 28] and N-Ras Q61R mutants, as well as different receptor tyrosine kinases, overexpression of homeobox (HOX) genes [29, 30]. Developmental pathways encompass among others hedgehog, 
the epidermal growth factor receptor (EGFR), the Stem Cell-Like Factor (SCF) receptor KIT, Wnt/ $\beta$-catenin, Notch, stromal cellderived factor-1 (SDF-1)/CXC Chemokine Receptor-4 (CXCR4) and vascular endothelial growth factor (VEGF)/VEGFR receptor $[23,31,32]$. Such growth factors cooperate and activate distinct parts of the tumorigenic downstream signalling paths and various Epithelial-Mesenchymal Transition (EMT)-associated molecules, including phosphatidylinositol 3'-kinase (PI3K)/Akt/ molecular target of rapamycin (mTOR), nuclear factor-kappa B (NF-кB), macrophage inhibitory cytokine-1 (MIC-1), vimentin, snail and twist [26].

In short, approximately $50 \%$ of CMM harbor an activating BRAF mutation that leads to constitutive activation of downstream signalling through the MAPK pathway [33]. About $90 \%$ of these mutations result in the substitution of glutamic acid for valine at codon 600 (designated as the BRAF V600E mutation), although other activating mutations (e.g. BRAF V600K and V600R) are disclosed. In addition, activating mutations in the KIT gene [34], which encodes a receptor protein kinase in the MAPK pathway, are identified in limited but distinct subsets of CMM arising from the mucous membranes, acral skin and chronically sun-damaged skin [35].

This review revisits insights in molecular dermatopathology focusing on the pathogenesis and diagnosis of CMM. It mainly targets molecular genetics referring to the molecular structure and the function of chromosomes. The covered methods are primarily used both for research projects and diagnostic purposes.

\section{Dedicated CMM sampling methods}

Detection of single CMM cells in the skin by immunocytochemistry is technically possible. More recently molecular detection procedures have been used increasingly to identify disseminated CMM cells in organs remote from the primary tumor. On principle, cDNA of disseminated tumor cells is amplified millions of times following the Polymerase Chain Reaction (PCR). Hence, discrete amounts of such tumor cells are possibly detected. However, tumor cells must exhibit specific changes in its genome or mRNA expression pattern helping its distinction from the surrounding cells. As solid tumors are notable for their genetic heterogeneity, the detection of tumorspecific genomic changes at the single cell level remains complex. Each individual primary CMM must be genotyped so that the corresponding patient-specific genetic lesion is conveniently identified and the appropriate PCR probes (primers) selected.

Dual dedicated sampling methods are especially useful for molecular dermatopathology [23]. First, laser cutting dissection helps to circumscribe under the microscope some cell populations thus increasing the homogeneity of tissue isolates based on morphological criteria [36, 37]. Second, tissue microarrays represent ordered sets of minute tissue core collections (from $0.6 \mathrm{~mm}$ to $1.0 \mathrm{~mm}$ in diameter) obtained from diverse specimens embedded in a single paraffin block [7]. Comparative, immunohistochemistry and a range of molecular methods are conveniently applied to tissue microarrays. Different CMM samples at different stages of progression are possibly used for disclosing distinct successive molecular alterations. Sequential biopsies and molecular profiling are other important tools both in research and CMM care. They shed some light on mechanisms underlying CMM progression and help to set up appropriate treatment strategies for patients.

Cell suspensions form blood marrow and peripheral blood are possibly used in molecular detection for identifying disseminated CMM cells. To reduce risk of contaminations, various steps of procedure including post-PCR steps are occasionally performed in different laboratories from that used for RNA extraction, cDNA synthesis and preparation of PCR mixtures.

\section{Molecular morphobiology}

Various molecular methods have been designed over time. The goal of molecular biology techniques is to improve the sensitivity and specificity in this field of diagnostics. To this end, two general types of molecular targets are distinguished:

1.Germline mutations in predisposition genes are searched for estimating individual risk, but they are not suited for staging purposes.

2.Tumor-specific gene mutations provide grading information with prognostic value. However, their complex mutation pattern does not allow for allele-specific amplification, making it difficult to identify mutated alleles in a high background of wild type alleles. However, the detection of these mutations is feasible using capillary electrophoresis. The technology disclosed about detect $1 / 10^{5}-1 / 10^{6}$ mutated alleles.

\section{Chromosomal G banding method}

The Chromosomal G Banding (CGB) method discloses some gross aberrations in chromosomes under microscopic examination [23]. CMM cell cultures are observed after metaphase freezing of mitotic figures. Enzyme digestion and histochemical staining reveal CGB. Of note, subtle chromosomal aberrations including point mutations, small insertions and discrete deletions, as well as subtle rearrangements commonly remain undisclosed using the CGB method.

\section{In situ hybridization}

In situ hybridization (ISH) demonstrates morphological aspects of specific DNA and RNA sequences in either tissue sections, single cells or chromosome spreads [38, 39]. Labeled single or double strands of DNA or RNA sequences containing complementary sequences hybridize to DNA or RNA under appropriate conditions to form stable hybrids [38]. The probe length for ISH optimizes tissue penetration and high hybridization rate.

Primed in situ (PRINS) labeling relies on a primer-mediated DNA synthesis carried out in situ on tissue sections. The procedure starts with annealing an oligonucleotide DNA primer adjacent to the target DNA region. Such molecular structure serves as a primer for the Tag polymerase incorporating the four 
nucleotides dATP, dGTP, dCTP and the labeled dUTP which is conveniently revealed using immunohistochemistry.

The ISH and PRINS methods are used for localizing DNA sequences and specific mRNA in cells and tissues, as well as visualizing chromosomes for interphase cytogenetics and detection of specific mRNA. Thus, ISH and PRINS methods were developed using chromosome-specific probes or oligonucleotides for detecting the density and nature of chromosome aberrations in interphase nuclei.

\section{FISH method}

Fluorescence in situ hybridization (FISH) results from hybridization of fluorescent complementary DNA probes recognizing specific genes and DNA oligonucleotides [40, 41]. It is performed either on fresh or formalin-fixed tissue sections, nuclei spreads or tissue microarrays. Probes correspond to sequences of the whole genome, centromeres, telomeres and specific gene regions. FISH targets mutated cells including those at distance from clinically recognized CMM. The number of spots per nucleus is expected to correspond to the copy number of the scrutinized chromosome locus. A translocation is detected by a spot splitting into distinct parts, or by different fluorescent probes that hybridize on each part of the translocated genes. Sets of FISH variants were developed in various ways. The methods allow detecting subtle chromosome aberrations in CMM [42-46]

One pitfall of the FISH method results from the limited entrapping of the nuclei volume in the tissue sections causing technical omissions of chromosomal segments. Hence, a number of nuclei have to be scrutinized before ensuring reliable assessments of the copy number of the investigative probe [47, 48].

\section{CGH method}

Comparative genomic hybridization (CGH) matches DNA from a melanocytic tumor to DNA from a normal control tissue from the same patient. The CGH method is performed using fresh or formalin-fixed tissue $[42,49]$. The DNAlabeled with fluorochromes is next hybridized on normal metaphase chromosomes or on arrays of small spots of DNA. Data are expressed as a gain or loss of copy number [50]. CGH helps identifying some genome aberrations and imbalances in CMM [51, 52], but only when genome aberrations are enough expressed in neoplastic cells [37]. CGH is mainly used in research settings [53] where it identifiers genome signatures distinguishing different melanocytic tumors. Of note, Spitz nevi (melanocytomas) [54, 55] at the difference with CMM contain genetic aberrations corresponding to single $11 \mathrm{p}$ gains. CMM arising in congenital melanocytic nevi show $\mathrm{CGH}$ patterns comparable to regular CMM, while some other atypical melanocytic neoplasms (melanocytomas) contain a number of aberrations of entire chromosomes, which are seen only in a minority of CMM [35].

\section{Gene microarray method}

Gene microarrays target RNA and microRNA (miRNA) expression [49]. They also scrutinize DNA mutations and polymorphism $[56,57]$. Indeed, mutations altering proteins as a result of amino acid substitution differ from silent mutations (polymorphism) affecting a given amino acid. The gene microarray method involves immobilization of selected specific DNA sequences on a solid platform, to which complementary labeled DNA hybridizes. The immobilized DNA corresponds to either oligonucleotides or complementary DNA. The labeled DNA is obtained from reverse-transcription of RNA extracted from the test tissue. Following the hybridization process, the labeled spots are scrutinized. The complexity of interpreting the multiple data requires refined statistical analysis and computerized mathematical models.

Gene micro arrays establish a molecular classification of CMM and melanocytic nevi [58-60]. In such screening procedure, many different gene signatures are found between melanocytic nevi and CMM.

\section{PCR and RT-PCR methods}

PCR substrate corresponds to DNA. Reverse transcriptase polymerase chain reaction (RT-PCR) uses RNA (reverse transcription and amplification), extracted from fresh or formalin-fixed tissue. A chemical reaction driven by cyclic thermal changes leads to a specific and exponential amplification of small fragments of the target DNA or RNA over a short period of time. Solid CMM tumors are notably enriched a large genetic heterogeneity. Hence the detection of tumor-specific genomic changes at the single cell level is complex. Each individual primary CMM should be suntinized and identified for the genotype and the selected PCR primer probes.

PCR identifies CMM micrometastases using some selected markers $[23,61]$. Indeed, molecular detection procedures help identifying dissemitted CMM cells in organs remote from the primary tumor. Their DNA is massively amplified by PCR, and that any minute amount of CMM cells is detected when they harbor specific alterations in their genome or mRNA expression pattern for a distinction from surrounding regular cells. The specificity of CMM cell identification represents a great challenge. The detection of micrometastases holds great promise for CMM staging. The identification of single CMM cells is possible in tissue and bodily fluids in both experimental and clinical samples. mRNA expression is distinctly upregulated by diverse cytokines and growth factors. The different levels of background expression makes the diagnostic specificity of RT-PCR tests difficult to assess. In addition, there is a great variety of methods for sampling, specimen processing, nucleic acid recovery and test conditions making impossible any comparison of data.

While immunohistochemistry improves the sensitivity in metastasis detection compared with regular histopathology, RTPCR for CMM-related marker gene expression, like tyrosinase and Melan A-Mart-1, was reported to increase the detection of suspected occult metastases up to 70\% [23]. Indeed, RT-PCR is expected to detect one CMM cell out of $10^{6}-10^{7}$ non-CMM cells, while immunohistochemistry probably detects one CMM cell in about $10^{4}-10^{5}$ non-CMM cells [20]. The relevance of PCR detection of CMM micrometastases in lymph nodes was, however, 
challenged because of the apparent lack of relevant prognostic value of the findings. Indeed, in addition to the identification of CMM micrometastases within sentinel lymph nodes, both the size and location of the metastasis should be assessed [62-67]. Thus, the role of non-microscopic methods for investigating the sentinel lymph node currently remains uncertain. In such assessments, histopathology reveals the location, size and nature of the suspected CMM cells. Misinterpretation of nodal nevus cells as a metastasis is unlikely.

Currently, detection of single tumor cells by amplification of tissue-specific gene expression using RT-PCR is the most sensitive technique, using mRNA reverse transcription and amplification of gene expression specifically associated CMM cells. Hence, RTPCR represents the molecular level of tumor markers known in immunochemistry, but with a higher analytical and diagnostic sensitivity. A number of markers and their use in detecting micrometastases have been described.

Standardization is difficult in RT-PCR. The background on RNA expression by normal cells in the sample is difficult to control as well as the stochastic effects governing the data of single RT-PCR reactions.

In situ PCR-based amplification of target nucleic acid sequences is possible before performing ISH. In situ PCR is performed on cell suspensions or tissue sections fixed and permeabilized, respecting the morphology and allowing access of PCR probes to the intranuclear sequences to be amplified. Cell suspensions or tissue sections are overlaid with PCR reagents, sealed off with a coverslip and submitted to thermal cycling. PCR products are detected using PCR probes (indirect in situ PCR) or through direct detection of labeled nucleotides incorporated into PCR products (direct in situ PCR).

\section{MLPA method}

Multiplex Ligation-Dependent Probe Amplification (MLPA) relies on annealing a set of probes. Each of them corresponds to a pair of oligonucleotides that hybridize next each other on a specific chromosome site [68-72]. In addition to target-specific sites, both oligonucleotides contain a universal PCR primer. One oligonucleotide harbors a stuffer sequence with a probespecific length. Following ligation of the hybridized adjacent oligonucleotides, the probe is amplified using PCR primers. As each probe has a unique length due to its stuffer sequence, electrophoresis points to the amount of PCR product related to the DNA copy number. Mutation-specific MLPA combines copy number detection and hot-spot mutations in a single assessment 8. Different CMM types are possibly distinguished [73].

\section{HRMA method}

High-resolution melting analysis (HRMA) is a rapid method based on DNA dissociation after heating. It allows to detect single base pair sequence variations [74]. Hot-spot mutations and mutated cells are detected when present in over $5 \%$ of a background of cells showing wild-type DNA $[75,76]$.

\section{Germline and somatic CMM mutations}

Multiple dysplastic nevi are a marker of CMM risk and other cancer susceptibility as well. Presence of a set of dysplastic melanocytic nevi associated with increased CMM risk predominantly occur in families with p16 (CDKN2A) mutations $[71,77]$. CMM is therefore likely to share cancer genes with other neoplasms because CMM is common in the family cancer syndrome. However, searching for such p16 mutations is clinically inrelevant in other CMM patients due to the weak probability of detecting the mutation [78]. A number of different p16 mutations have been reported so far [79]. The prevalence of familial p16 mutations is linked to the number of CMM in relatives. Globally, p16 mutations are present in $25-40 \%$ of CMM families with more than two CMM, while the proportion of p16 mutations is lower in families with two CMM only [79]. In addition, individuals with multiple primary CMM are more likely to have p16 mutations [80].

The 16 gene produces two different polypeptides, identified is the $\mathrm{p} 16 / \mathrm{INK} 4 \mathrm{a}$ and the $\mathrm{p} 14 / \mathrm{ARF}$ proteins. Both of them in part control the cell cycle of proliferation. The exon mutation leads to alteration in the p16 and/or p14 functions. In contrast, most non familial sporadic CMM appear unrelated to germline p16 mutations. A set of other common genes of lower penetrance is probably involved in sporadic CMM. Such mutations increase with the disease progression [81].

Genetic aberrations in CMM correlate with some specific phenotypes. Individuals with BRCA2 and BRCA1 mutations present an increased risk of CMM $[82,83]$.

The progression from a regular melanocyte to a CMM cell includes some morphological changes, and a set of yet unravelled genetic aberrations. Both the MAPK signalling pathway [33] and the PTEN/AKT pathway are involved in the growth control (proliferation, apoptosis) of melanocytes. Activation of these pathways following somatic mutations in the RAS and RAF genes likely represent one of the initial steps in the development of melanocytic nevi. The BRAF oncogene on the 7Q34 chromosome part is commonly mutated in the majority of CMM, but is absent in giant congenital melanocytic nevi $[84,85]$

Although some dozens of different BRAF mutations have been identified in 24 different codons, each mutation is usually rare. The V600E mutation in exon 15 is notably dominant, and accounts for most of the mutations in CMM. V600 is also possibly, mutated in other parts including V600K $(\approx 16 \%)$ and V600R or V600D $(\approx$ $3 \%)$. Rare mutations of neighbouring codons in BRAF exon 16 are also identified [86]. Thus, PCR amplification of BRAF exon 15 followed by conventional dideoxy sequencing is commonly used for the identification of BRAF mutations. However, this method suffers from limited sensitivity for detecting BRAF mutations that are present in low percentages $(<20 \%)$ in a sample [86]. This could occur when a specimen is heavily contaminated by non-CMM tissues or due to the intratumor heterogeneity in BRAF V600 mutations [86]. Thus, to avoid false-negative results by sequencing, microdissection of formalin-fixed paraffinembedded sections to enrich CMM cells before DNA extraction is recommended. This is particularly important when genotyping is performed using thin primary CMM tissues. 
A number of sensitive methods are available for detecting BRAF V600E mutations. However, the level of validation and characterization of these tests is variable [87]. Real-time PCR uses complementary primers that define a 116-base pair sequence of human genomic DNA containing the BRAF codon 600 site in exon 15 and two fluorescent oligonucleotide probes. One probe detects the wild type BRAF V600 sequence, and the other detects the V600E mutation sequence.

CMM with multiple melanocytic nevi and BRAF mutation occur more frequently at a younger age and on intermittently sun-exposed sites [86]. By contrast, p53 mutations are more common in lentigo maligna and CMM developed on chronically sun-exposed sites of older patients exhibiting prominent actinic damages [86]. Distinct somatic gene mutations such as at the cKIT locus were identified in other CMM, particularly those on the mucosa, palms and soles and in the hyperpigmented CMM variant [82]. Genes potentially involved in CMM metastases include BRAF and RAS of the MAPK pathway [89]. CMM therapies targeting the BRAF and cKIT pathways call for genotyping CMM in order to select the proper patients [90-95].

Blue nevi, Spitz melanocytomas, congenital melanocytic nevi and uveal CMM do not or rarely contain BRAF mutations. By contrast, they contain other mutations such as in the NRAS or HRAS genes. In addition, somatic mutations of GNAQ in the RAS-like domain were found in both uveal CMM and blue nevi. Similarly to BRAF mutations, the RAS and GNAQ mutations possibly cause MAPK activation and form an alterative route for melanocytic neoplasia. Even if these mutations represent early events in the development of melanocytic neoplasms, they do not cause melanocytic progression towards CMM.

While activating BRAF mutations are common in CMM on non-chronic sun damaged skin, activating mutations in KIT have been found in CMM originating from acral skin, mucosa and or sum-protected skin. Over 20 KIT mutations have been identified in CMM, most of which are point mutations causing a leucine to proline substitution at codon 576 in exon 11. They correspond to about one third of KIT mutations in CMM [92]. As mutations affect multiple codons, conventional sequencing following PCR amplications of exons $11,13,17$ and 18 is necessary to identify KIT mutations. Some CMM harbor KIT mutations in exon 11, and less commonly in exons 13,17 and 18. Mutations in exon 9 have not been reported in CMM. Immunohistochemical detection of KIT protein using anti-CD117 antibody does not reliably predict the KIT mutation status $[31,96]$.

\section{Heterogeneity in BRAF and KIT mutations}

In CMM, the intertumoral heterogeneity of BRAF V600E mutations has been demonstrated using paired samples of primary $\mathrm{CMM}$, and single or multiple metastases obtained from the same patient $[94,97]$. This is likely explained by the intratumoral heterogeneity of BRAF mutations in primary CMM that is, both BRAF wild-type cells and BRAF mutated cells coexist in primary $\mathrm{CMM}$, and both subclones could give rise to metastasis. Such intertumor heterogeneity has significant implications when using RAF kinase inhibitors, because, in contrast to BRAF V600E
CMM cells, BRAF wild-type cells are resistant to, and are even stimulated by, RAF kinase inhibitors [98].

Similar intertumor heterogeneity of KIT mutations has also been demonstrated in limited series of cases. KIT genotypes were different between primary tumors and corresponding lymph node metastases [85].

Instead of genotyping tumor tissues that show intertumor genetic heterogeneity, examining circulating tumor cells in peripheral blood provides valuable information for molecular targeted therapy. Molecular characterization of circulating tumor cells supports a strategy for real-time noninvasive monitoring for tumor genotypes which is conveniently repeated during the course of therapy to monitor the emergence of drug-resistant mutations.

\section{Conclusion}

The spontaneous evolution of CMM is dramatic. The biology of its constitutive cells is complex and terogeneous in each tumor and the significance of micrometastases is poorly understood. Attempting to cope with each features call for dermatopathology including immunohistochemistry and various types of molecular procedures. CMM differs from other skin cancers because of the greater potential to discriminate to distant organs. Most of the molecular advances available in dermatopathology usually remain research-based approaches. In such settings, molecular diagnosis appears increasingly important for predicting the biological behavior of CMM [13]. Indeed, understanding CMM biology is crucial for the development of active target therapies. Some markers are correlated with poor prognosis. Translational research indicates that CMM tumors correspond to genetically heterogeneous neoplasms with different risk phenotypes and genotypes.

About $60 \%$ of all CMM express somatic mutations in the BRAF protein, and the vast majority of these neoplasms express the oncogenic activating V600E mutation. Clearly, with the recognition of such molecular defects, and treatment with BRAF inhibition, a larger number of the metastatic CMM patients experience neoplastic shrinkage and improved clinical benefits. The identification and blocking of abnormal signalling through the MAPK pathway represent improved therapeutic strategy. However, despite the advances in translational research, many current therapeutic responses remain transitory. Molecular biology should contribute to elucidate the resistances to targeted therapies, and how to block the reactivation of the MAPK pathway following initial success in BRAF inhibition. Other molecular influences such as those related to genders, are further involved in CMM initiation [99].

\section{Acknowledgements}

No sources of funding were used to assist in the preparation of this manuscript. The authors have no conflicts of interest that are directly relevant to the content of this review. The authors appreciate the excellent secretarial assistance of Magali Caes. 


\section{References}

1. MacKie RM, Hauschild A and Eggermont AM. Epidemiology of invasive Cutaneous melanoma. Ann Oncol 20. 2009;20(6):1-7.

2. Brochez L, Verhaeghe E, Grosshans E, Haneke E, Piérard G, Ruiter D, et al. Inter-observer variation in the histopathological diagnosis of clinically suspicious pigmented skin lesions. J Pathol 2002;196(4):459-466. DOI: 10.1002/path.1061.

3. Piérard-Franchimont C, Hermanns-Lê T, Delvenne P and Piérard GE. Dormancy of growth-stunted malignant melanoma: sustainable and smoldering patterns. Oncology Reviews. 2014;8(2):54-59. DOI:doi org/10.4081/oncol.2014.252.

4. Piérard GE. Cell Proliferation in Cutaneous Malignant Melanoma: Relationship with Neoplastic Progression. Int Scholarly Res Network Dermatol. 2012;2012: 828146. doi: 10.5402/2012/828146.

5. Nasr, Michel R, El-Zammar, Ola. Comparison of pHH3, Ki-67, and survivin immunoreactivity in benign and malignant melanocytic lesions. Am J Dermatopathol. 2008;30(2)117-122.

6. Ohsie SJ, Sarantopoulos GP, Cochran AJ and Binder SW Immunohistochemical characteristics of melanoma. J Cutan Pahtol. 2008;35(5):433-444. DOI: 10.1111/j.1600-0560.2007.00891.x.

7. Alonso SR, Ortiz P, Pollan M, Pérez-Gomez B, Sanchez L, Acuna MJ et al. Progression in cutaneous malignant melanoma is associated with distinct expression profiles. Am J Pathol. 2004;164(1):193-203. DOI: doi.org/10.1016/S0002-9440(10)63110-0.

8. Fecher LA, Cummings SD, Keefe MJ and Alani RM. Toward a molecular classification of melanoma. J Clin Oncol. 2007;25(12):1606-1620. doi: 10.1200/JC0.2006.06.0442.

9. Vitoux D, Mourah S, Kerob D, Verola O, Basset-Seguin N, Baccard M, et al. Highly sensitive multivariable assay detection of melanocytic differentiation antigens and angiogenesis biomarkers in sentinel lymph nodes with melanoma micrometastases. Arch Dermatol. 2009;145(10):1176-1177. doi:10.1001/archdermatol.2009.230.

10. Bernaba BN, Vogiatzis PI, Binder SW and Cassarino DS. Potentially useful markers for desmoplastic melanoma: an analysis of KBA.62, p-AKT, and Ezrin. Am J Dermatopathol. 2011;33(4):333-340.

11. Nielsen PS, Riber-Hansen $\mathrm{R}$ and Steiniche T. Immunohistochemical double stains against Ki67/MART1 and HMB45/MITF: promising diagnostic tools in melanocytic lesions. Am J Dermatopathol. 2011;33(4):361-370.

12. Piérard GE, Piérard-Franchimont $\mathrm{C}$ and Delvenne P. Malignnt melanoma and its stromal nonimmune Microecosystem. J Oncol. 2012:2012:8

13. Piérard GE, Piérard-Franchimont C, Hermanns-Lê T, Piérard S.I. and Delvenne P. Fractal and spectral analyses of peritumoral skin melanoma. Austin J Cancer Clin Res. 2015;2(7):1057.

14. Carlson JA, Ross JS and Slominski A. New techniques in dermatopathology that help to diagnose and prognosticate melanoma. Clin Dermatol. 2009;27(1):75-102. doi: 10.1016/j. clindermatol.2008.09.007.

15. Blokx WAM, van Dijk MC and Ruiter DJ. Molecular cytogenetics of cutaneous melanocytic lesions - diagnostic, prognostic and therapeutic aspects. Histopathology. 2010;56(1):121-132.

16. Bogenrieder $\mathrm{T}$ and Herlyn M. The molecular pathology of cutaneous melanoma. Cancer Biomark. 2011;9(1-6):267-286.

17. Dadzie OE, Neat M, Emley A, Bhawan J and Mahalingam M. Molecular diagnostics. An emerging frontier in dermatopathology. Am J Dermatopathol. 2011;33(1):1-16.

18. Gaudi S and Messina JL. Molecular bases of cutaneous and uveal melanomas. Patholog Res Int. 2011;2011(2011):159421.

19. Dadras SS. Molecular diagnostics in melanoma: current status and perspectives. Arch Pahtol Lab Med. 2011;135(7):860-869.

20. Espinosa E, Berrocal A, Lopez Martin JA, Gonzalez Cao M and Cerezuela P. Advances in cutaneous melanoma. Clin Transl Oncol. 2012;14(5):325-332.

21. Mathew R and Messina JL. Recent advances in pathologic evaluation and reporting of melanoma. Semin Oncol. 2012;39(2):184-191. doi:10.1053/j.seminoncol.2012.01.005.

22. Moore DA, Pringle JH and Saldanha GS. Prognostic tissue markers in melanoma. Histopathology. 2012;60(5):679-689.

23. Reginster MA, Piérard-Franchimont C, Piérard GE and Quatresooz P. Molecular dermatopathology in malignant melanoma. Dermatol Res Pract. 2012:2012(2012):6.

24. Swick JM and Maize JC Sr. Molecular biology of melanoma. J Am Acad Dermatol. 2012;67(5):1049-1054. doi:10.1016/j.jaad.2011.06.047

25. Van den Hurk K, Niessen HE, Veeck J, van den Oord JJ, van Steensel MA, Zur Hausen A, et al. Genetics and epigenetics of cutaneous malignant melanoma : a concent out of tune. Biochim Biophys Acta. 2012;1826(1):89-102. doi:10.1016/j.bbcan.2012.03.011.

26. Mimeault M and Batra SK. Novel biomarkers and therapeutic targets for optimizing the therapeutic management of melanomas. World J Clin Oncol. 2012;3(3):32-42. doi: 10.5306/wjco.v3.i3.32.

27. Davies H, Bignell R, Cox C, Philip Stephens, Sarah Edkins, Sheila Clegg, et al. Mutations of the BRAF gene in human cancer. Nature. 2002;417:949-954.

28. Forth M, Wouters J, de Chaumont C, Dynoodt P and Gallagher WM. Prognostic and predictive biomarkers in melanoma: an update. Expert Rev Mol Diagn. 2016;16(2):223-2237.

29. Maeda K, Hamada J, Takahashi Y, Tada M, Yamamoto Y, Sugihara T, et al. Altered expressions of HOX genes in human cutaneous malignant melanoma. Int J Cancer. 2005;114(3):436-441.

30. Piérard GE and Piérard-Franchimont C. HOX gene aberrant expression in skin melanoma. J Skin Cancer 2012;2012(2012):4.

31. Davies JR, Randerson-Moor J, Kukalizch K, Harland M, Kumar R, Madhusudan $\mathrm{S}$, et al. Inherited variants in the MC1R gene and survival from cutaneous melanoma: a BioGenoMEL study. Pigment Cell Melanoma Res. 2012;25(3):384-394. doi: 10.1111/j.1755148X.2012.00982.x.

32. $\mathrm{Hu}$ YY, Zheng $\mathrm{MH}$, Zhang R, Liang YM, Han $\mathrm{H}$. Notch signalling pathway and cancer metastasis. Adv Exp Med Biol. 2012;727:186198. doi:10.1007/978-1-4614-0899-4_14.

33. Piérard GE, Piérard-Franchimont C, Leonard B, Delvenne P. The MAP kianase cascade. A key target for treatments in skin cancerology. Rev Med Liege. 2013;68(12):650-654.

34. Curtin JA, Busam K, Pinkel D, Bastian BC. Somatic activation of KIT in distinct subtype of melanoma. J Clin Oncol. 2006;24(26):4340-4346.

35. Ascierto PA, Grimaldi AM, Curti B, Faries MB, Ferrone S, Flaherty $\mathrm{K}$, et al. Future perspectives in melanoma research. J Transl Med. 2012;10:83. doi:10.1186/s12967-015-0736-1.

36. Dadzie OE, Yang S, Emley A, Keady M, Bhawan J, Mahalingam M. 
RAS and RAF mutations in banal melanocytic aggregates contiguous with primary cutaneous melanoma-clues to melanomagenesis Br J Dermatol. 2009;160(2):368-375. doi:10.1111/j.13652133.2008.08887.x.

37. Uribe P, Wistuba II, Gonzalez S. Allelotyping, microsatellite instability, and BRAF mutation analyses in common and atypical melanocytic nevi and primary cutaneous melanomas. Am J Dermatopathol. 2009;31(4):354-363. doi:10.1097/DAD.0b013e318185d205.

38. Yelamos O, Busam KJ, Lee C, Meldi Sholl L, Amin SM, Merkel EA, et al. Morphologic clues and utility of fluorescence in situ hybridization for the diagnosis of nevoid melanoma. J Cutan Pathol. 2015;42(11):796806. doi:10.1111/cup.12627.

39. Leachman SA, Cassidy PB, Chen SC, Curiel SC, Curiel C, Geller A, et al. Methods of melanoma detection. Cancer Treat Res. 2016;167:51105. doi:10.1007/978-3-319-22539-5_3.

40. Gerami P, Jewell SS, Morrison LE, Blondin B, Schulz J, Ruffalo T, et al. Fluorescence in situ hybridization (FISH) as an ancillary diagnostic tool in the diagnosis of melanoma. Am J Surg Pathol. 2009;33(8):11461156. doi:10.1097/PAS.0b013e3181a1ef36.

41. Newman MD, Lertsburapa T, Mirzabeigi M, Mafee M, Guitart J, Gerami P. Fluorescence in situ hybridization as a tool for micro staging in malignant melanoma. Mod Papthol. 2009;22(8):989-995. doi:10.1038/modpathol.2009.72.

42. de la Fouchardière A, Vergier B. Molecular diagnostic contribution in melanocytic lesions analysis (FISH/CGH). Ann Pathol. 2011;31:S115-S116. doi:10.1016/j.annpat.2011.09.006

43. Pouryazdanparast P, Cowen DP, Beilfuss BA, Haghighat Z, Guitart J, Rademaker A et al. Distinctive clinical and histologic features in cutaneous melanoma with copy number gains in 8q24. Am J Surg Pathol. 2012;36(2):253-264. doi:10.1097/PAS.0b013e31823425cc.

44. Fang Y, Dusza S, Jhanwar S and Busam K. Fluorescence in situ hybridization (FISH) analysis of melanocytic nevi and melanomas: sensitivity, specificity and lack of association with sentinel node status. Int J Surg Pathol. 2012;20(5):434-440.

45. Gammon B, Beilfuss B, Guitart J, Gerami P. Enhanced detection of spitzoid melanomas using fluorescence in situ hybridization with 9p21 as an adjunctive probe. Am J Surg Pathol. 2012;36(1):81-88 doi:10.1097/PAS.0b013e31822d5ff8.

46. Senetta R, Paglierani M, Massi D. Fluorescence in situ hybridization analysis for melanoma diagnosis. Histopathology. 2012;60(5):706714. doi:10.1111/j.1365-2559.2011.03984.x.

47. Jeuken JW, Sprenger SH, Wesseling P. Comparative genomic hybridization: practical guidelines. Diagn Mol Pathol.2002;11(4):193203.

48. Patton EE, Mathers ME, Schartl M. Generating and analyzing fish models of melanoma. Methods Cell Biol. 2011;105:339-366. doi:10.1016/B978-0-12-381320-6.00014-X.

49. Saldanha G, Elshaw S, Sachs P, Alharbi H, Shah P, Jothi A, et al. MicroRNA-10b is a prognostic biomarker for melanoma. Mod Pathol. 2016;29(2):112-121. doi:10.1038/modpathol.2015.149.

50. Koroknai V, Ecsedi S, Vizkeleti L, Kiss T, Szasz I, Lukacs A, et al. Genomic profiling of invasive melanoma cell lines by array comparative genomic hybridization. Melanoma Res. 2016;26(2):100107. doi:10.1097/CMR.0000000000000227.

51. Bauer J, Bastian BC. Distinguishing melanocytic naevi from melanoma by DNA copy number changes: comparative genomic hybridization as a research and diagnostic tool. Dermatol Ther. 2006;19(1):40-49.

52. Yang XR, Brown K, Landi MT, Ghiorzo P, Badenas C, Xu M, et al. Duplication of CXC chemokine genes on chromosome 4q13 in a melanoma-prone family. Pigment Cell Melanoma Res. 2012;25(2):243-247. doi:10.1111/j.1755-148X.2012.00969.x.

53. Da Forno PD, Fletcher A, Pringle JH, Saldanha GS. Understanding spitzoid tumours :new insights from molecular pathology. Br J Dermatol. 2008;158(1):4-14.

54. Murphy MJ, Jen M, Chang MW, Grant-Kels JM, Makkar H. Molecular diagnosis of a benign proliferative nodule developing in a congenital melanocytic nevus in a 3-month-old infant. J Am Acad Dermatol 2008;59(3):518-523. doi:10.1016/j.jaad.2008.05.011.

55. Piérard GE, Piérard-Franchimont C. Cutaneous melanocytomas: variants and caveats. Austin J Cancer Clin Res. 2015;2(3):1035.

56. Kunz M, Ibrahim SM, Koczan D, Scheid S, Thiessen HJ, Gross G. DNA microarray technology and its applications in dermatology. Exp Dermatol. 2004;13(10):593-606.

57. Koh SS, Opel ML, Wei JPJ, Yau K, Shah R, Gorre ME, et al. Molecular classification of melanomas and nevi usinggene expression microarray signatures and formalin-fixed and paraffin-embedded tissue. Mod Pathol. 2009;22(4):538-546. doi:10.1038/modpathol.2009.8.

58. Van Dijk MC, Rombout PD, Boots-Sprenger SH, Straatman H, Bernsen MR, Ruiter DJ, et al. Multiplex ligation-dependent probe amplification for the detection of chromosomal gains and losses in formalin-fixed tissue. Diagn Mol Pathol. 2005;14(1):9-16.

59. Scolyer RA, Murali R, McCarthy SW, Thompson JF. Pathologic examination of sentinel lymph nodes from melanoma patients. Semin Diagn Pathol. 2008;25(2):100-111.

60. Cook MG, Di Palma S. Pathology of sentinel lymph nodes for melanoma. J Clin Pathol. 2008;61:897-902. doi:10.1136/jcp.2006.042036

61. Lovly CM, Dahlman KB, Fohn LE, Su Z, Dias-Santagata D, Hicks DJ, et al. Routine multiplex mutational profiling of melanomas enables enrolment in genotype-driven therapeutic trials. PLoS One. 2012;7:e35309. doi.org/10.1371/journal.pone.0035309

62. Rangel J, Nosrati M, Leong SP, Haqq C, Miller Jr, Sagebiel RW, et al. Novel role for RGS1 in melanoma progression. Am J Surg Pathol. 2008;32:1207-1212. doi:10.1097/PAS.0b013e31816fd53c.

63. Cesinaro AM, Schirosi L, Bettelli S, Migaldi M, Maiorana A. Alterations of 9p21 analysed by FISH and MLPA distinguish atypical spitzoid melanocytic tumours from conventional Spitz's nevi but do not predict their biological behaviour. Histopathology 2010;57(4):515527. doi:10.1111/j.1365-2559.2010.03653.x.

64. Conway C, Beswick S, Elliott F, Chang YM, Randerson-Moor J, Harland $\mathrm{M}$, et al. Deletion at chromosome arm 9p in relation to BRAF/NRAS mutations and prognostic significance for primary melanoma. Genes Chromosomes Cancer. 2010;49(5):425-438. doi: 10.1002/gcc.20753

65. Kutzner H, Metzler G, Argenyi Z, Requena L, Palmedo G, Mentzel T, et al. Histological and genetic evidence for a variant of superficial spreading melanoma composed predominantly of large nests. Mod Pathol. 2012;25(6):838-845. doi:10.1038/modpathol.2012.35.

66. Ogbah Z, Pig-Butille JA, Simonetta F, Badenas C, Cervera R, Mila J, et al. Molecular characterization of human cutaneous melanoma-derived cell lines. Anticancer Res. 2012;32(4):1245-1251.

67. Poliseno L, Haimovic A, Segura MF, Hanniford D, Christos PJ, Darvishian F, et al. Histology-specific microRNA alterations in melanoma. J Invest Dermatol.2012;132(7):1860-1868. doi:10.1038/ 


\section{jid.2011.451.}

68. Bunyan DJ, Skinner AC, Ashton EJ, Sillibourne J, Brown T, Collins AL, et al. Simultaneous MLPA-based multiplex point mutation and deletion analysis of the dystrophin gene. Mol Biotechnol 2007;35(2):135-140.

69. Bishop DT, Demenais F, Goldstein AM, Bergman W, Bishop JN, Bressac-de-Paillerets $B$, et al. Geographical variation in the penetrance of CDKN2A mutations for melanoma. J Natl Cancer Inst. 2002;94(12):894-903.

70. Newton Bishop JA and Gruis NA. Genetics: what advice for patients who present with a family history of melanoma? Semin Oncol.2007;34(6):452-459.

71. Goldstein AM, Cahn M, Harland M, Hayward NK, Demenais F, Bishop DT, et al. Features associated with germline CDKN2A mutations: a GenoMEL study of melanoma prone families from three continents. J Med Genet. 2007;44(2):99-106.

72. Helsing P, Nymoen DA, Ariansen S, Steine SJ, Maehle L, Aamdal S, et al. Population based prevalence of CDKN2A and CDK4 mutations in patients with multiple primary melanomas. Genes Chromosomes Cancer. 2008;47(2):175-184.

73. Freedberg DE, Rigas SH, Russak J, Gai W, Kaplow M, Osman I, et al. Frequent p16-independent inactivation of p14ARF in human melanoma. J Natl Cancer Inst. 2008;100(11):757-759. doi: 10.1093/ jnci/djn 157

74. Pinzani P, Santucci C, Mancini I, Simi L, Salvianti F, Pratesi N. BRAFV600E detection in melanoma is highly improved by COLDPCR. Clin Chim Acta. 2011;412(11-12):901-905. doi: 10.1016/j. cca.2011.01.014.

75. Dahl C and Guldberg P. The genome and epigenome of malignant melanoma. APMIS. 2007;115(10):1161-1176.

76. Singh M, Lin J, Hocker TL and Tsao H. Genetics of melanoma tumorigenesis. Br J Dermatol. 2008;158(1):15-21.

77. Richmond-Sinclair NM, Lee E, Cummings MC, Williamson R, Muller K, Green AC. Histologic and epidemiologic correlates of p-MAPK, Brn2, p53 and p16 immunostaining in cutaneous melanoma. Melanoma Res. 2008;18(5):336-345. doi: 10.1097/CMR.0b013e32830d8329.

78. Davies H, Bignell GR, Cox C, Stephens P, Edkins S, Clegg S, et al. Mutations of the BRAF gene in human cancer. Nature. 2000;417(6892):949-954

79. Goldstein AM, Chan M, Harland M, Hayward NK, Demenais F, Bishop DT, et al. Features associated with germline CDKN2A mutations: a GenoMEL study of melanoma-prone families from three continents. J Med Genet. 2007;44(2):99-106.

80. Helsing P, Nymoen DA, Ariansen S, Steine SJ, Maehle L, Aamdal S, et al. Population-based prevalence of CDKN2A and CDK4 mutations in patients with multiple primary melanomas. Genes Chromosomes and Cancer. 2008;47(2):175-184.

81. Bataille V. Genetic epidermiology of melanoma. Eur J Cancer. 2003;39(10):1341-1347.

82. Bollag G, Hirth P, Tsai J, Zhang J, Ibrahim PN, Cho H, ET AL. Clinical efficacy of a RAF inhibitor needs broad target blockade in BRAFmutant melanoma. Nature. 2010;467(7315):596-599. doi: 10.1038/ nature 09454

83. Lutzky J, Bauer J and Bastian BC. Dose-dependent, complete response to imatinib of a metastatic mucosal melanoma with a K642E KIT mutation. Pigment Cell Melanoma Res. 2008;21(4):492-493. doi: 10.1111/j.1755-148X.2008.00475.x.
84. Ichii-Nakato N, Takata M, Takayanagi S, Takashima S, Lin J, Murata $\mathrm{H}$, et al. High frequency of BRAFV600E mutation in acquired nevi and small congenital nevi, but low frequency of mutation in mediumsized congenital nevi. J Invest Dermatol. 2006;126(9):2111-2118.

85. Wu D, Wang M, Wang X, Yin N, Song T, Li H, et al. Lack of BRAF ${ }^{6000 E}$ mutations in giant congenital melanocytic nevi in a Chinese population. Am J Dermatopathol. 2011;33(4):341-344. doi: 10.1097/ DAD.0b013e3181fb5bc7.

86. Sondergaard JN, Nazarian R, Wang Q, Guo D, Hsueh T, Mok S, et al. Differential sensitivity of melanoma cell lines with BRAFV600E mutation to the specific RAF inhibitor PLX4032. J Translat Med. 2010;8:39-50. doi: 10.1186/1479-5876-8-39.

87. Viros A, Fridlyand J, Bauer J, Lasithiotakis K, Garbe C, Pinkel D, et al. Improving melanoma classification by integrating genetic and morphologic features. PLoS Med. 2008;5(6):e120. doi: 10.1371/ journal.pmed.0050120.

88. Maldonado JL, Fridlyand J, Patel H, Jain AN, Busam K, Kageshita T, et al. Determinants of BRAF mutations in primary melanomas. J Natl Cancer Inst. 2003;95(24):1878-1890.

89. Sakaizawa K, Goto Y, Kiniwa Y, Uchiyama A, Harada K, Shimada S, et al. Mutation analysis of BRAF and KIT in circulating melanoma cells at the single cell level. Br J Cancer. 2012;106(5):939-946. doi: 10.1038/ bjc.2012.12.

90. Curtin JA, Busam K, Pinkel D and Bastian BC. Somatic activation of KIT in distinct subtypes of melanoma. J Clin Oncol. 2006;24(26):43404346.

91. Rubinstein JC, Sznol M, Pavlick AC, Ariyan S, Cheng E, Bacchiocchi A. Incidence of the $\mathrm{V} 600 \mathrm{~K}$ mutation among melanoma patients with BRAF mutations and potential therapeutic response to the specific BRAF inhibitor PLX4032. J Transl Med. 2010;8:67. doi: 10.1186/1479-5876-8-67.

92. Woodman SE, Davies MA. Targeting KIT in melanoma: a paradigm of molecular medicine and targeted therapeutics. Biochem Pharmacol. 2010;80(5):568-574. doi: 10.1016/j.bcp.2010.04.032

93. Anderson S, Bloom KJ, Vallera DU, Rueschoff J, Meldrum C, Schilling R, et al. Multisite analytic performance studies of a real-time polymerase chain reaction assay for the detection of BRAF V600E mutations in formalin-fixed, paraffin-embedded tissue specimens of malignant melanoma. Arch Pathol Lab Med. 2012;136(11):1385-1391. doi: 10.5858/arpa.2011-0505-OA

94. Emri G, Adany R and Balazs M, Lázár V, Ecsedi S, Vízkeleti L, et al. Marked genetic differences between BRAF and NRAS mutated primary melanomas as revealed by array comparative genomic hybridization. Melanoma Res. 2012;22(3):202-214. doi: 10.1097/ CMR.0b013e328352dbc8.

95. Yancovitz M, Litterman A, Yoon J, Ng E, Shapiro RL, Berman RS, et al. Intra-and inter-tumor heterogeneity of BRAF (V600E) mutations in primary and metastatic melanoma. PLoS ONE. 2012;7(1):e29336. doi: 10.1371/journal.pone.0029336.

96. Torres-Cabala CA, Wang WL, Trent J, Yang D, Chen S, Galbincea J, et al. Correlation between KIT expression and KIT mutation in melanoma: a study of 173 cases with emphasis on the acral-lentiginous/ mucosal type. Mod Pathol. 2009;22(11):1446-1456. doi: 10.1038/ modpathol.2009.116.

97. Colombino M, Capone M, Lissia A, Cossu A, Rubino C, De Giorgi $\mathrm{V}$, et al. BRAF/NRAS mutation frequencies among primary tumors and metastases in patients with melanoma. J Clin Oncol. 2012;30(20):2522-2529. doi: 10.1200/JC0.2011.41.2452. 
98. Poulikakos PI, Zhang C, Bollag G, Shokat KM, Rosen N. RAF inhibitors transactivate RAF dimers and ERK signalling in cells with wild-type BRAF. Nature. 2010;464(7287):427-430. doi: 10.1038/nature08902.
99. Hermanns-Lê T, Piérard S. Streamlining Cutaneous Melanomas in Young Women of the Belgian Mosan Region. BioMed Res Int. 2014;10:320767. 